Schengen's Excluded:

Third Country Nationals and EU Citizenship Regimes on the Polish-German Border

\author{
Andrew D. Asher \\ Indiana University Bloomington \\ asherand@indiana.edu
}




\title{
Schengen's Excluded: Third Country Nationals and EU Citizenship Regimes on the Polish-German Border
}

\begin{abstract}
This article investigates how the supranational policies of European Union (EU) citizenship were experienced by "third country nationals" living as non-citizen residents in the transnational urban space of Słubice, Poland and Frankfurt(Oder), Germany-two cities separated only by the Polish-German border. With an emphasis on the implementation of the Schengen acquis-the EU's common policies on cooperation in law enforcement, visas, and the management of its borders--this article begins with an examination of the ways in which third country nationals are categorized as a group separate from EU citizens. This article then explores how the everyday presence of the border between Słubice and Frankfurt(Oder) excluded third country nationals from the exercise of EU citizenship through practices that placed limits on their freedom of movement. Finally, this article describes how specific individuals responded to these limitations by strategically managing their visa and citizenship statuses.

Because of the cities' unique border location, the residents of Słubice/Frankfurt(Oder) demonstrate the development of unequal citizenship regimes for EU citizens and non-citizens, in which each group is extended differential access to the entitlements, privileges, and rights of citizenship. By exploring how third country nationals' ability to exercise citizenship rights were structured and constrained by EU laws and regulations, this article documents the emergence of one instance of illiberality within the EU's ostensibly neoliberal and democratic economic and political projects, and brings into sharp relief the central role the right to free movement plays in the exercise of full citizenship within the EU.
\end{abstract}

Keywords: EU Citizenship, Citizenship Regimes, Schengen Acquis, Poland, Germany

Running Head: Schengen’s Excluded 


\section{Schengen's Excluded: Third Country Nationals and EU Citizenship Regimes on the Polish-German Border}

\section{Introduction}

"I don’t have a visa. . . I dream about going to Germany, but I don’t know how." Nadia, a Ukrainian student living in Stubice, Poland, was continually reminded of this frustration by the panoramic view of Frankfurt(Oder), Germany, that accompanied her daily walk along the Polish-German border to her university. In contrast to her Polish and German contemporaries, who have enjoyed visa-free travel between their countries since 1991, Nadia was unable to obtain a Schengen area visa and had therefore never been permitted to make the five minute trip across the Oder River to visit the German side of the two cities' transnational urban area. Like many citizens of non-European Union states, or "third country nationals," living in Frankfurt(Oder) and Słubice, Nadia experienced the everyday proximity of the border as a type of social exclusion; a limitation on her freedom of movement that distinguished her as an outsider not only in the cities' locally transnational spaces, but also in the supranational spaces created by the European Union (EU).

Situated about 80 kilometers east of Berlin, Słubice and Frankfurt(Oder) share about 90,000 residents, and only became separate cities in the wake of World War II, when the comprehensive Allied negotiations at the Yalta and Potsdam Conferences realigned Poland's post-war borders. Słubice was "founded" in 1945 after the new Polish-German border was located at the Oder and Neisse Rivers, placing the eastern district of Frankfurt(Oder), then called Dammvorstadt, inside Poland. Like most towns located in the territories Poland "recovered" from Germany, Słubice's German residents 
were expelled ${ }^{1}$ and replaced primarily by resettled Poles, many of whom had also been compelled to leave Polish territories annexed by the Soviet Union in what is today western Ukraine and Belarus. Słubice thus became a relatively small and isolated town located on a highly contested and tightly controlled border which was very difficult, if not impossible, for average border residents to cross in either direction during most of the 45 years between 1946 and $1991 .^{2}$

After Poland applied for EU membership in 1994, Słubice/Frankfurt(Oder)'s presumptive location on one of the EU's future internal borders positioned the cities at the center of policymakers' efforts to expand the EU's common market through the elimination of barriers to the free movement of people, goods, services, and capital, in an ongoing project of deterritorialization that works against several of the most entrenched functions of state borders. Borders are extremely potent symbols of state power, and are places not only where the practices, techniques, and tactics of Foucaultian governmentality are particularly visible and personally encountered (Foucault 1991:102, cf. Donnan and Wilson 1999), but also where populations, the "terrain par excellence of [modern] government,” can be delineated, managed and regulated (Miller and Rose 1990:2, cf. Brubaker 1992:27-31, Foucault 2007:105, Inda 2005:4). In this regulatory function, state borders act as powerful mediators of identity by separating individuals into different categories (e.g. “national,” “alien,” “asylum seeker,” "legal permanent resident," etc.) based on the relationship between the traveler and the government whose border is being crossed.

Poland's EU accession on May 1, 2004, and subsequent adoption of the Schengen acquis--the EU's common policies on visas, cooperation in law enforcement, the 
management of its external borders, and the elimination of its internal borders ${ }^{3}$--was supposed to make border controls between Słubice and Frankfurt(Oder) obsolete. However, because Poland had not fully implemented the acquis’s requirements prior to accession, it remained outside of the Schengen area's border-free zone for a little over three-and-a-half more years. For this reason, the border checkpoint on the bridge between the cities stayed anachronistically in place until December 21, 2007 (Council of the European Union 2006b:13), and third country nationals continued to require both Polish and Schengen visas in order to maintain access to both sides of the city-space.

Michel Foucault observes that the effective operation of the apparatuses of security, that is, the mechanisms and calculations modern forms of governmentality use to determine the optimum parameters within which to manage the well-being of a population, both requires and creates freedom of movement, specifically, "the possibility of movement, change of place, and processes of circulation of people and things” (2007:48-49, cf. 6,63, Gordon 1991:20-21). In the course of establishing its common market, the EU has scaled up this concept for use at the transnational level. Indeed, the principle of free movement is one of the most fundamental of the EU's governing values and one of the core rights of EU citizenship (cf. D’Oliveira 1995). The EU's foundational document--the 1992 Treaty on European Union (TEU, commonly known as the Maastricht Treaty)--requires member states to "maintain and develop the Union as an area of freedom, security and justice, in which the free movement of persons is assured,"4 and create "an internal market characterized by the abolition. . . of obstacles to the free movement of goods, persons, services and capital." 5 The Maastricht Treaty goes on to make free movement of persons a hallmark of its newly established definition of EU 
citizenship, stating, "Every citizen of the Union shall have the right to move and reside freely within the territory of the Member States. ${ }^{6}$,

EU citizens also appear to regard mobility as one of the Union's most important attributes. In response to a 2006 Eurobarometer question, "What does the European Union mean to you personally?” 50\% of EU citizens answered, “freedom to travel, study and work anywhere in the European Union," ${ }^{77}$ a rate of response more than twice as high as “democracy” (at 24\%) and five times higher than "social protection” (at 10\%) (Eurobarometer 2007:73). Nevertheless, because the Maastricht Treaty grants EU citizenship automatically and exclusively to the citizens of the member states, ${ }^{8}$ the principle of free movement is not extended to the approximately 16 million third country nationals who reside within the EU. ${ }^{9}$ For these individuals, the Maastricht Treaty powerfully demonstrates the exclusionary function of citizenship as a membership category which divides those who are entitled to full participation in a community from those who are not (Brubaker 1992, Cohen 1999, Soysal 1994, Tilly 1996).

In this article, I utilize the lens of mobility to respond in two ways to Andrew Kipnis's call for increased ethnographic focus on the legal structures of citizenship in order "to lay the basis for the theoretical construction of citizenship as an independent axis for the analysis of both social difference and inequality” (2004:258). First, I examine how the techniques and technologies of governmentality (Foucault 1991, 2007) contained within the Schengen acquis's regulations and procedures systematically constitute third country nationals and EU citizens as separate legal categories that are subject to different degrees of mobility, security, and surveillance. Nikolas Rose and Peter Miller have described these governmental technologies as the "complex of 
mundane programs, calculations, techniques, apparatuses, documents and procedures through which authorities seek to embody and give effect to governmental ambitions” (1992:175, cf. Inda 2005:8). In this way, studying the “microphysics of power” (Miller and Rose 1990:8) resulting from the institutionalization of the Schengen acquis at Słubice/Frankfurt(Oder)'s border checkpoint reveals one aspect of an EU-wide enactment of varying and unequal “citizenship regimes” (D. Anderson 1996, Humphrey 1999) for EU and third country citizens. By subjecting the members of each group to different citizenship practices, these citizenship regimes configure the terms under which individuals have access to, and can make demands for, the entitlements, privileges, and rights of citizenship (D. Anderson 1996, cf. Wiener 1998:30).

Second, I investigate how the presence of a Schengen border between Słubice and Frankfurt(Oder) obliged third country nationals to respond to the regulations it imposed either by accepting limits on their freedom of movement, or, more often, by strategically managing their citizenship statuses. By so doing, these individuals exhibited a type of “flexible citizenship,” whereby economic calculation becomes “a major element in diasporean subjects' choice of citizenship,” as they "both circumvent and benefit from different nation-state regimes” (Ong 1999:112). In Słubice/Frankfurt(Oder), where the local economic space was divided between two national markets, this flexibility was often a matter of financial necessity, and many third country nationals sought EU citizenship through naturalization in Poland or Germany simply as a way to guarantee continuous access to economic opportunities in both cities.

This article is based on 18 months of fieldwork conducted with third country nationals living in Słubice/Frankfurt(Oder) between 2003 and 2006 as part of a 
comprehensive study of the experience and meanings EU citizenship in the two cities during the liminal period between Poland's EU accession in 2004 and the elimination of the checkpoints along the Polish-German border at the end of 2007 (see Asher 2008). At the beginning of 2005, Frankfurt(Oder) had a foreign population of 2,824, accounting for $4.4 \%{ }^{10}$ of its total population of 64,656 , or a level about half of Germany's national average of $8.8 \%{ }^{11}$ In comparison, 230 foreign residents ${ }^{12}$ were registered in gmina Słubice as of $2006,{ }^{13}$ amounting to $1.1 \%$ of its total population of 20,212 , or a proportion similar to Poland's national average of about 1.8\%. ${ }^{14} 80 \%$ (185) of Słubice's foreign residents were third country nationals, 66\% (152) were from former Soviet republics (excluding EU members Latvia, Lithuania, and Estonia), and 44\% (102) were from Ukraine. ${ }^{15}$ Although it includes individuals living in both cities, the breakdown of citizenships in my sample also roughly follows this distribution. All but two of the seventeen correspondents who participated in in-depth interviews for this article originated in the former Soviet Union, and eleven originated in Ukraine. As the above figures suggest, Słubice and Frankfurt(Oder) are not destinations for large migrant populations. Nevertheless, because they lack citizenship in any of Słubice/Frankfurt(Oder)'s three local spaces_-Poland, Germany, and the EU-third country nationals are particularly "good to think with” as they document one instance of the considerable “degree of 'illiberality’ in [the] supposedly neoliberal world” (Kipnis 2004:266, cf. Torpey 2000:166) of EU citizenship by virtue of their exclusion from it. 


\section{Everyday Exclusions}

As the physical location of the Schengen border checkpoint, the bridge linking Frankfurt(Oder) and Słubice was a liminal space where individual mobility between the two cities was regulated personally and directly, and where third country nationals were differentiated from their Polish and German neighbors. For third country nationals who were authorized to cross it, the bridge was sometimes experienced as transcendent and deterritorialized space that invoked a sense of freedom. Lyudmyla, a Belarusian graduate student who lived in Frankfurt(Oder) and held both Polish and Schengen visas, described this sensation, “There aren’t borders for me now. . . I [enjoy] the feeling of freedom here. On the bridge, I feel like I am in Neverland, neither Germany nor Poland-in between.” Olena, a Russian student in European Studies, echoed this experience, "I have a feeling of freedom on the bridge. . .I don’t know where I am. I never had that feeling before.”

Conversely, the inability to cross the bridge brought into sharp relief the EU's exclusionary policies toward third country nationals, as well as the importance of freedom of movement to the full exercise of citizenship within the EU. Perhaps because of this experience, almost all of my correspondents had, at one time or another, applied for a visa to visit the side of the border "across from" where they lived. For residents of Frankfurt(Oder) this was a relatively straightforward matter, requiring a trip of a little over an hour to the Polish consulate in Berlin. In contrast, for Słubice residents, obtaining a Schengen visa necessitated a journey of about four to six hours to the German consulate in Wrocław, a trip that routinely demanded two full working days due to the consulate's schedule and the lack of public transport connections from Słubice. Coupled with unpredictable results, the expense in time and money of this trip made it extremely 
difficult for third country nationals living in Słubice to continuously maintain a valid Schengen visa.

An individual who lacked a visa for one side of the border was subject to a host of small and seemingly banal exclusions that, when taken together, fundamentally altered the experience and quality of life provided by the two cities. For example, a third country national who resided in Słubice without a Schengen visa could not shop in Frankfurt(Oder)'s larger and often cheaper clothing stores, watch a film at the cities' only movie theater, attend a play or a concert at Frankfurt(Oder)'s performing arts center, spend an afternoon on the beach at the nearby Helenesee, or travel from the region's nearest major airport in Berlin. Similar exclusions applied to third country nationals living in Frankfurt(Oder) without a Polish visa, but given Słubice's smaller size and less developed infrastructure, the list was not as extensive, and primarily included a loss of access to cheaper restaurants, services, groceries, gasoline, cigarettes and other products on the Polish side of the border (cf. Asher 2005:133-135). As an intrinsically transnational space, an individual who lacked access to both cities was prevented from fully participating in local social and economic life, a situation that often gave rise to a profound sense of alienation. Aleksandra, a Ukrainian secondary school teacher who lived in Słubice and held a Schengen visa intermittently, explained, "It feels better when you can cross the border. You can buy things with better quality and at a lower price. It was always difficult when friends cross the border for festivals, concerts, the Helenesee ... and you can't go. I could live without [crossing the border], and I still can live without it ... and I will have to [her current visa was just about to expire]. But it is better when you can go.” 


\section{Codifying Difference}

Third country nationals’ experience of alienation at the Polish-German border was far from accidental. In fact, the Schengen acquis’s border procedures were explicitly intended to have an identity-generating component (Wiener 1998:115,185-186,229). The process of passing through a Schengen checkpoint is meant to foster a personal identification with EU citizenship as a membership category by promoting a sense of community, solidarity, and fraternity among EU citizens as they are physically separated from non-citizens and subjected to less rigorous levels of surveillance and regulation. The EU citizen/non-citizen binary is formally codified in the Schengen Common Manual, ${ }^{16}$ which mandates different protocols for third country nationals as part of its uniform border procedures. According to the Common Manual (Part 2, Point 1.3.1), only a "minimum check” involving a "rapid and straightforward” verification of the validity of travel documents is necessary for nationals of Schengen member states, while third country nationals require "thorough checks” involving "detailed” verification of travel documents, visas or residence permits, the individual's origin and destination (and supporting documents if necessary), sufficient means of subsistence, and finally, that "the person, his vehicle and the objects he is transporting are not likely to jeopardise public policy, national security or international relations” of the member states. ${ }^{17}$

Unlike most Schengen border crossings, the Słubice/Frankfurt(Oder) checkpoint did not have the requisite separate lanes for member state and third country citizens. ${ }^{18}$ However, it still achieved the effect of physical separation by following the Common Manual's prescription of placing the documents presented by third country nationals 
under greater scrutiny. During the day-to-day operation of the checkpoint, the identification cards or passports of Poles and Germans (the vast majority of EU citizens crossing at between Frankfurt(Oder) and Słubice) were rarely checked electronically and were usually only given a brief visual check before the individual was waved through--a process which took only a few seconds for each side of the border. While rarely subjected to the full requirements of the Common Manual's thorough check, nonSchengen passports were almost always scanned electronically, visually checked, verified for visas and previous entry/exit stamps, and finally stamped again, usually by both the Polish and German border guards. This process could take several minutes or longer depending on the officer's level of suspicion. During this time, long and impatient lines of EU nationals quickly formed, making the position of the third country national as an outsider plainly and uncomfortably clear. A feeling of embarrassment or humiliation was one of the most common complaints third country nationals made about the border checkpoint, and are feelings I experienced personally during many of my trips between the cities with my own--albeit still comparatively privileged--third country passport from the United States. Through this more intense surveillance, Schengen border practices effectively reinforce the status of third country nationals as potentially dangerous and untrustworthy "foreigners" who must continually justify and verify themselves and their movements. This is the essence of the difference in citizenship regimes produced and reinforced by the Schengen acquis, and is a dynamic reflected in the results of a survey I conducted in 2005 on frequent border-crossers at the cities' two universities, ${ }^{19}$ in which $48 \%$ of respondents from non-Schengen countries characterized the border as "very 
strict" or "strict” compared to only 18\% from Schengen member countries (primarily Germany) and $11 \%$ from Schengen signatory countries (primarily Poland). ${ }^{20}$

\section{The Power of Stamps}

Even for third country nationals who held both Polish and Schengen visas, specific aspects of the Schengen acquis's practices of governmentality, such as variations in the stamping of passports, functioned to limit their cross-border mobility and further structure distinctions between EU citizens and non-citizens. Entry and exit stamps were a ubiquitous part of the Słubice/Frankfurt(Oder) border checkpoint, and were a lasting reminder that even as EU citizens are allowed to travel freely with no record of their journeys, the cross-border movements of third country citizens must be documented and verifiable. A 2004 Council of the European Union (henceforth Council) regulation requires "the travel documents of third country nationals ... [to be] systematically stamped on entry and exit," ${ }^{\text {21 }}$ while the Common Manual simultaneously assures that "no entry stamp shall be affixed to the documents of nationals of the Member States of the European Community.”22 When placed in the transnational context of Słubice/Frankfurt(Oder), this simple difference in a routine border procedure was transformed into a powerful device for limiting the movements of third country nationals. This power worked through what would seem to be an almost inconsequential aspect of Foucaultian governmentality: the dimensions of a passport.

A standard machine-readable international passport measures approximately 125 by 85 millimeters (IACO 2003), and an EU entry/exit stamp about 43 by 30 millimeters. This provides space for only four non-overlapping stamps per visa page, but between six 
and eight if they are overlapped (as is common practice). Given these constraints, passports of third country nationals attempting to use both sides of Słubice/Frankfurt(Oder)'s urban space were filled extremely quickly if the EU's stamping regulation was fully observed and they received two entry and two exit stamps for each round trip across the border. For example, a Ukrainian passport contains 32 pages, 27 of which are visa pages available for stamps. Subtracting two pages for Schengen area and Polish visas, this leaves enough space in a new passport for about 50 round trips. At a rate of only one cross-border trip per week--about average for the cities’ residents--a new Ukrainian passport would last at a little less than a year, even though it is designed to be valid for 10 years. Perhaps with this problem in mind, the border guards at the Słubice/Frankfurt(Oder) checkpoint rarely followed the stamping regulation completely, and some of my correspondents reported occasional success in convincing an individual officer not to apply a stamp. Nevertheless, stamping, and the subsequent need to renew passports, were widely considered by third country nationals to be significant problems introduced by Poland's implementation of the Schengen acquis, as well as Germany's stricter enforcement of its protocols.

Prior to, and even immediately following, Poland's EU accession, stamps appear to have been less frequently applied at the Słubice/Frankfurt(Oder) checkpoint. In my survey of frequent border crossers, 90\% of non-Schengen passport holders reported receiving stamps either "always” or "often” in 2005, compared to 75\% between May 1 and December 31, 2004, and 72\% prior to Poland's EU accession (May 1, 2004). The stamping record contained in my own passport also indicates this increase. In 2003, I made 72 round-trips across the border and received a total of 23 stamps (21 from the 
Polish side, and two from the German side), or about one stamp every three trips. In 2004, I crossed 18 times and received only three stamps (two Polish and one German), and in 2005 and 2006, I made 43 round trips across the border, and received 88 stamps (37 from the Polish side and 51 from the German side), or about two stamps per trip-a more than six fold increase over 2003. Like many of my correspondents, even though I was legally authorized to travel freely between the cities, in order to conserve space in my passport, I was forced to decrease the frequency of my border crossings in proportion to the number of stamps I received. Compared to 2003, when I made my 72 trips in only 86 days, I crossed the border more than seven times less often in 2005 and 2006, when it took me 370 days to make the 43 trips.

A passport with too many stamps can have further negative implications. First, a passport lacking enough space to apply a stamp can be cause for a border guard to deny its bearer entry, and must therefore be renewed, a procedure that typically necessitates the renewal of all the visas in it. For third-country nationals with both visas, this means a minimum of three trips to different consular offices, as well as the expenses, paperwork, processing times, and uncertainties of approval that are typical of visa and passport bureaucracies. Second, passports with many entry and exit stamps from a single border checkpoint can precipitate greater scrutiny at other border crossings and in consular offices, where these stamps often translate into suspicions of trafficking activities and further difficulties in obtaining visas.

Vasyl, a Ukranian musician living in Słubice, was surprised to be denied a Schengen visa when he brought a new passport to the German consulate. He recalled, "I had [a visa] last year, but this year the fascists didn’t give me one! I brought an empty 
passport to the embassy--I had renewed it--and they said 'you must have done something, [that's why] you renewed it' (e.g. a refusal of entry or illegal border crossing indicated by a stamp in the passport ${ }^{23}$ ). I brought the same documents as last time, but they didn’t like my face this time.“ The denial had immediate economic repercussions for Vasyl by preventing him from playing concerts in Germany. Consequently, Vasyl decided to apply for Polish citizenship, and was eventually approved, pending his renunciation of his Ukrainian citizenship. He viewed this decision as a pragmatic way to ensure the mobility required of his profession, explaining, "Until the time I get Polish citizenship, Europe is closed to me.”

Because of difficulties like Vasyl's, most third country nationals residing in Słubice/Frankfurt(Oder) carefully planned and managed their cross-border movements in order to minimize the stamps they received. For example, Isabela, a Romanian university student who lived in Frankfurt(Oder), explained to me that she had to drop out of a course I taught at the university in Stubice (ironically, on the topic of European borders) because she had decided to schedule all the classes she attended in Poland on the same day in order to conserve space in her passport and avoid running out of pages for stamps before the end of the semester. Several of my other correspondents reported being forced to give up visiting one side of the border altogether. This type of self-limitation on crossborder movement demonstrates the powerful disciplining effect the Schengen acquis can have over the individual, so much so that even when a third country national had de jure freedom of movement by virtue of obtaining the proper visas, routine border practices and regulations, such as the use of passports to provide a physical record of its bearer's movement, placed a de facto limitation on the exercise of this freedom. In this way, the 
administration of the Schengen acquis in Słubice/Frankfurt(Oder) contributed to a citizenship regime in which third country nationals were functionally less mobile than EU citizens; an inequality that worked at cross-purposes to the Maastricht Treaty's neoliberal goal of transforming the EU into an unimpeded social and market space.

\section{A Local Solution}

Recognizing the problem that the Schengen stamping regulation presented for third country citizens living in Słubice and Frankfurt(Oder), the local border authorities developed a limited solution based on a liberal interpretation of another of the Common Manual's provisions (Part 2, Point 2.1.6), which reads, “Exceptionally, at the request of an alien, insertion of an entry or exit stamp may be dispensed with if insertion might cause serious difficulties for that person. In that case, entry or exit must then be recorded on a separate sheet indicating the name and passport number." ${ }^{24}$ While this section is more likely intended to protect individuals who might fear repercussions in their home country resulting from travel to the EU, such as political dissidents or human rights advocates, the obligation to renew one's passport too frequently was considered a serious enough difficulty by local border officials to allow third country nationals to request a letter on which to receive entry/exit stamps.

However, the process of obtaining this letter in Słubice and Frankfurt(Oder) was not a simple matter. Because the practice makes use of a discretionary area of the Common Manual's regulations (and a somewhat dubious interpretation of its intentions), the border guard did not readily advertise the existence of the measure, and an individual was required to make separate requests to the local commanders on each side of the 
border in their respective national languages. In my own case, I made requests on both sides of the border, but was only able to complete the process on the Polish side, as the German officials failed to return my correspondence after an initial reply. Upon receiving my inquiry, the Polish regional Komendant required a personal meeting in order to approve the letter, at which I was asked to provide proof of my affiliation with Słubice's university (through a letter of invitation), my status as a researcher in Poland (through letters from the United States Department of Education and the United States Embassy in Warsaw), and a formal letter of request detailing my circumstances.

After examining my passport and visa, and observing that I should really be making the request on the German side since most of the stamps were from the German authorities, the Komendant asked for my residency registration card (potwierdzenie zameldowania), which I did not have. An uncomfortable moment followed as I attempted to explain why, after living in Słubice for more than six months, I had still not obtained the card without openly admitting that I had failed to properly register my residence with the local police. The Komendant apparently decided this was not a major infraction, and after a few more questions, agreed to approve my request. Once my documents were photocopied for their records, I was given two sheets of standard A4 paper bearing my name, citizenship, passport number, the stamp of the Komendant, and an expiration date that corresponded to the last day of my visa. I was instructed to present these papers only on the Polish side of the checkpoint between Stubice and Frankfurt(Oder), and never to present them to the German officials or at any other border checkpoint in Poland, since they could potentially be construed as false documents. 
Because they were often unable to follow the exact requirements of Poland's residency registration system, or were disinclined to voluntarily subject themselves to the additional scrutiny and surveillance involved in completing the request, only a handful of third country citizens I met had obtained a letter. Even so, the existence of a local border policy that used of one aspect of the Schengen border regulations to circumvent another less convenient aspect of these same regulations — even if it applied only to the third country citizens that were able to justify their need to frequently cross the borderillustrates the extent to which Frankfurt(Oder) and Słubice's border authorities were willing to accommodate the imperatives of the cities' unique transnational space. The next section examines the analogous personal compromises and citizenship strategies many third country nationals were willing to make in order to accommodate the requirements of living along a Schengen border.

\section{Strategies of Citizenship}

Within the modern nation-state system, restrictions on personal freedom of movement are inherently linked to the question of "how the economic advantages available in a particular area [are] to be divided up, whether these [involve] access to work or to poor relief” (Torpey 2000:19). This is also true within the EU's common market, where efforts to enable transnational labor mobility and market access for member state citizens through the expansion EU-level citizenship rights simultaneously necessitated supranational policies to manage the movements of third country nationals (Wiener 1998, Kostakopoulou 2001). Indeed, one of the core functions of the Schengen 
acquis is to push outward the regulatory nexus of market access from the borders of the member states to the external borders of the Schengen area.

Unlike EU citizens, who are allowed--with certain exceptions ${ }^{25}$-- free access to all the national labor markets within the EU, third country nationals are limited to the terms of their work and residence permits, which almost always restrict them to work available in their country of residence, and sometimes to a single firm. For this reason, the question of economic advantage for third country nationals in Stubice/Frankfurt(Oder) usually took the form of how to gain access to the financial opportunities afforded by cross-border travel. All except one of my correspondents moved to Stubice/Frankfurt(Oder) either for immediate economic benefit, or for the future advantages provided by the "European” degrees available at the cities” universities. A third of my correspondents also depended on cross-border access for at least part of their income, despite the tenuousness of their visa situations. Among my correspondents living in Słubice, residence in Poland was viewed both as economic opportunity in its own right and as stepping-stone for gaining access to the Schengen area, and it was generally agreed that receiving a Schengen visa in Poland (with its status as an EU member state and Schengen signatory) was considerably less difficult than in their home countries. This conclusion was supported by considerable anecdotal evidence gleaned from personal experience and from the reports of friends, family, and acquaintances.

Acquiring Polish citizenship was also used as a way not only to guarantee an individual's economic position in Poland, but also to gain access to EU citizenship rights through the automatic conferral of EU citizenship. In keeping with Aihwa Ong's assertion that dynamics of globalization have produced a more flexible approach to 
citizenship in which economic calculation is a central element, (1999:112), three-quarters of my correspondents who lived in Poland had either naturalized as Polish citizens or had applied and were awaiting a decision. Like Vasyl, the economic imperatives generated by differences in the EU's citizenship regimes created a powerful pull towards obtaining EU citizenship for these individuals. Guaranteeing a position in Słubice/Frankfurt(Oder)'s labor markets and strategies to maximize economic benefits featured prominently in their immigration narratives, as is demonstrated by the following three examples.

Dmytry, a Russian secondary-school teacher from Kazakhstan, immigrated to Poland in 2000 after experiencing ethnic discrimination and becoming afraid that he might lose his job. His wife, Beata, is ethnically Polish, and because her maternal grandmother was deported from eastern Poland (now western Ukraine) in 1939, she was eligible for a Polish repatriation program and automatic citizenship. After deciding to move, Beata and Dmytry wrote over 50 letters to different Polish cities, and were eventually invited to settle in Słubice, where, as a Polish citizen, Beata was able to begin working immediately. As a foreign national, Dmytry had difficulties finding a job in his field, and during the four years he waited to receive Polish citizenship he "worked everywhere” in a series of short-term manual-labor jobs. Dmytry was finally able to find a teaching position at a school in Słubice only after he was granted citizenship. For him, citizenship was “...the most important thing... Before, it was difficult to get a job, since permission is given for a specific firm or school. Now I can change jobs quickly, and I'm not dependent on a piece of paper.” 
Ivan, a Ukrainian who traded in used appliances, was also pursuing Polish citizenship as a way to ensure access to the EU's economic markets. Ivan immigrated to Poland in 2000, and was in the process of making a heritage-based application for Polish citizenship, even though he did not identify himself as ethnically Polish. He chose to pursue Polish citizenship for economic reasons, and claimed that if he could apply for American or German citizenship he would eagerly do so. Ivan held a temporary residence card for Poland that had to be renewed yearly and did not grant him work authorization, but did help him, along with an invitation from a German colleague, to obtain a three-month Schengen visa. Ivan attributed the possibility of getting a Schengen visa directly to his residency in Poland, and said that it would have been much more difficult to receive the visa if he still lived in Ukraine. Holding a Schengen visa allowed him to purchase used appliances in Germany, which he transported to Ukraine for resale — a grey market activity that enabled him to exploit cross-border price differentials by virtue of his access to Polish, Ukrainian, and EU spaces.

Similarly, Larisa, a Ukrainian IT analyst, chose to live in Słubice as a way to strategically utilize the current Schengen border policies to her maximum benefit. Stubice's location permitted her to compete for work available on the German side of the border, while still allowing her parents to visit relatively easily from Ukraine. In order to secure both her position in Poland's labor market and her cross-border access to Germany, Larisa entered into a fraudulent marriage to obtain Polish citizenship. She found this arrangement preferable to marrying a German citizen and living in Germany, since she believed her parents might have problems getting a Schengen visa in Ukraine. 
Each of these narratives demonstrates the importance of acquiring EU citizenship to the full exercise of economic rights within the Union. The rights of labor market access and freedom of movement are fundamentally intertwined within the concept of EU citizenship, and exclusion from one can imply exclusion from the other. In order to function, the EU's transnational labor market requires the right of free movement. However, because economic self-sufficiency without the aid of social benefits continues to be a de facto requirement for the full exercise of this freedom-- particularly with regards to the right of residency --labor market access is essential to assuring mobility (Peebles 1997: 601-604). Without a legal claim to either of these rights, third country nationals are doubly disqualified, and must appeal to national citizenship policies in order to gain supranational citizenship rights. This dynamic reveals a central tension within EU citizenship. Even as EU citizenship policies and practices challenge its member states’ monopoly on the management and regulation of their populations, because national citizenship regulations determine the conditions under which a third country national can obtain EU citizenship, these same transnational policies continue to reinforce national understandings of citizenship identities.

In locations like Poland and Germany, where the concept of nationhood privileges common ethnicity and descent, and citizenship laws are based primarily on jus sanguines, proving a link to the ethnic nation through familial descent, or establishing a familial relationship by marriage to a citizen, is often the fastest and simplest way to achieve citizenship. ${ }^{26}$ These links, whether based on an advantage of personal history like Beata or Ivan’s demonstrably “Polish” ancestors, or a willingness to enter into a marriage of convenience like Larisa, become a form of social capital that helps determine which third 
country nationals will have the potential of gaining access to citizenship in an EU member state.

In many cases, this “trading up” of citizenship regimes also implies a loss, as member state regulations frequently require applicants for naturalization to give up their previous citizenship. ${ }^{27}$ Anastasiya, a conductor and instructor at Słubice's music school, immigrated to Poland in 1994 and was naturalized six years later. She wanted to maintain dual citizenship, but was required by the Polish authorities to renounce her Ukrainian citizenship. Because Anastasiya regularly crossed the border to participate in collaborative musical projects undertaken by Słubice and Frankfurt(Oder)--many of which were sponsored by EU funds--her continuous need to maintain a Schengen visa made keeping Ukrainian citizenship an impractical option. In effect, the difficulties imposed by the Schengen acquis eventually forced Anastasiya to choose between two exclusive citizenship regimes and compelled her to seek EU citizenship in spite of her professed fear of cultural assimilation and a lack of identification with either Poland or the EU. For Anastasiya, lacking the ability to cross the border presented an economic handicap was simply too costly to bear.

Because of the definitional link between EU citizenship and citizenship in a member state, the EU citizenship model, even with its emphasis on transnational and neoliberal ideas of economic viability (Peebles 1997), ultimately fails to supersede jus sanguines and jus soli-based models of national citizenship, and despite attempts to imagine the EU as a transnational or supranational community (Shore $2000 \mathrm{cf}$. B. Anderson 1983), the legal apparatuses of the member states remain the institutions with which actors "must negotiate in the final instance" within the domain of citizenship 
(Kastoryano 2003:194, 2002:170-172). Étienne Balibar has warned that this tacit incorporation of member states’ exclusionary citizenship practices within EU citizenship has the long-term potential of expanding the scope of the discrimination against third country nationals by fostering the development of a sustained system of asymmetric power relations distinguished by the restriction of third country nationals’ relative freedom of movement and access to economic spaces (2004:43-44, 121-124). The power of this discriminatory potential was displayed by my correspondents' great desire to gain EU citizenship and the lengths they would go to attain it. However, as is also demonstrated by my correspondents, for those who have the necessary social capital, the layering of EU citizenship onto national citizenship can provide a way to convert their status from categorical outsiders to citizens. In this way, Vasyl, Beata, Dmytry, Ivan, Larisa, and Anastasiya all made strategic use of the inclusionary aspects of Poland's national citizenship laws as a way to gain citizenship privileges in both national and transnational spaces, including, perhaps most critically, full access to the local crossborder space of Słubice/Frankfurt(Oder).

\section{Conclusions: Schengen's End}

In 2007, the Council of the European Union determined that Poland ${ }^{28}$ had sufficiently implemented the requirements of the Schengen acquis, and the border controls between Poland and Germany were eliminated at midnight on December 21. ${ }^{29}$ In Frankfurt(Oder) and Słubice, a crowd of around 5000 people gathered on the border bridge to celebrate with music and fireworks, and Frankfurt(Oder)'s mayor rode ceremonially in the last car controlled at the border checkpoint (Märkische Oderzeitung 
2007a, 2007b). Only Frankfurt(Oder)'s border guard, which stood to have 800 of its 1600 officials withdrawn from the region, seemed to object to the situation, and a month earlier many of its members had participated in a protest march through Frankfurt(Oder) warning that the Schengen expansion was premature and presented significant security concerns; claims that Germany’s interior minister, Wolfgang Schäuble, flatly denied (Deutsche Welle 2007, Märkische Oderzeitung 2007a).

While both countries continue to maintain mobile surveillance patrols along the Polish-German frontier, ${ }^{30}$ the focus of Poland's border security apparatus has shifted to its eastern borders, completing a process that began in 2003 when Poland unilaterally reintroduced visas for Ukrainian (as well as Russian and Belarusian) nationals as part of its harmonization with the Schengen acquis. ${ }^{31}$ In contrast to the Polish-German border, where waiting times were measured in minutes and searches were rare, as an external EU border, checkpoints on Poland's eastern frontier are being reinforced and expanded. According to several of my correspondents, these are the "real" borders of the EU, where travelers are subjected to full customs control, routine luggage and vehicle searches, and waiting times of several hours—practices that powerfully assert the exclusionary dynamics of the EU's citizenship regimes, as well as the differentiation of the EU as a separate economic and security space. For the EU, this is where the sorting and processing of third country nationals is supposed to occur: outside of the Schengen area and outside the common market.

For this reason, between 2004 and 2007 the checkpoints in Słubice/Frankfurt(Oder) and elsewhere along the Polish-German border were already structurally out of place in the midst of the EU's theoretically open market. However, the 
experience of third country nationals living in Słubice/Frankfurt(Oder) during the transition period between Poland's EU accession and the deregulation of the border is also instructive, as it acutely demonstrates how Schengen acquis systematically excludes and separates EU insiders from third country outsiders. At the Polish-German border, the implementation of the Schengen acquis increased surveillance for third country citizens, making the supposedly neoliberal moment of Poland's EU accession a disappointment as many people found their movements further limited by the acquis's practices and procedures. This experience reveals a more generalized reality facing third country nationals within the EU, one in which they are unequal to EU citizens in the realm of transnational citizenship. Although a single Schengen visa will now suffice for both sides of the border and restrictions on third country nationals’ mobility between Frankfurt(Oder) and Słubice have been lifted, third country nationals are still not extended other EU-wide economic rights, such as the right to work and the right to reside, and their construction as a structurally “foreign” group remains. Like any citizenship, the creation of the EU citizens simultaneously created non-citizens, and as social and economic rights expanded transnationally for these new EU citizens, the relative level of citizenship rights declined for third country nationals because they received no corresponding expansion.

By emphasizing freedom of movement for its citizens while simultaneously limiting resident third country nationals from accessing this freedom, the EU's citizenship regimes underscore the power differential that globalization creates between mobile and non-mobile subjects (Ong 1999:11). With a conception of citizenship organized around access to economic markets and economic viability, the neoliberal 
approach taken by EU policy encourages an entrepreneurial and flexible assessment of citizenship (Ong 1996:739), an approach that was exhibited by many third country nationals in Słubice/Frankfurt(Oder) as they utilized aspects of their personal histories to strategically gain access to EU citizenship through citizenship in a member state.

Two dynamics therefore illustrate the critical differences between the EU citizenship regimes experienced by third country nationals and EU citizens. First, EU citizenship policies segregate EU citizens and non-citizens through practices and regulations that construct EU citizens as freely mobile while simultaneously subjecting third country nationals to surveillance, verification, regulation, and limitation. In Słubice/Frankfurt(Oder), this process strongly divided third country nationals from their Polish and German counterparts by fundamentally altering the way they could experience the cities’ spaces. Second, the citizenship regime applied to third country nationals provides them with recourse to fewer transnational rights within the EU, especially with regard to the economic activity and mobility that is so important to the EU's neoliberal conception of the citizen. This distinction represents a type of "status inequality" (Schnapper 1998:117) that is an anathema to the creation of a supranational citizenship community within the EU, but nevertheless threatens to become one of its permanent features. 


\section{Notes}

1. In total, about 12 million ethnic Germans were expelled from Poland, about 7 million of which were from the recovered territories (deZayas 1979:xxv,5859,89).

2. The exception to this rule was 1972-1980, when the border was opened to limited cross-border traffic.

3. The Schengen acquis was incorporated into the EU's legal framework by the Treaty of Amsterdam, which came into effect on May 1, 1999. It collectively contains the provisions of the 1985 Schengen Agreement and the 1995 Schengen Convention, as well as later decisions. Although there is not an exact correspondence between Schengen and EU member states--the United Kingdom and Ireland are EU members, but not Schengen signatories, while Iceland, Norway and Switzerland are Schengen signatories, but not EU members - the Schengen border protocols treat all citizens of the European Economic Area (EEA), which includes Ireland and the United Kingdom, in the same way as citizens of Schengen member states. The slippage between the two memberships is small enough that in terms of EU identity politics, they can generally be understood as coterminous, and they are routinely treated as a single entity in both the media and everyday discourse. Because the distinction in memberships is not essential to my arguments, for the purposes of this article I also treat EU citizens and Schengen member state citizens as interchangeable groups.

4. TEU Art. B (Treaty on European Union (Consolidated Version) Art. 2). For the aid of the reader, when an EU Treaty is cited in this article, I indicate the original version first, followed by the most recent consolidated versions in parentheses.

5. TEU Art. G, Para. 3 (Treaty Establishing the European Community (Consolidated Version) Art. 3).

6. TEU, Art. G, Para. 9 (Treaty Establishing the European Community (Consolidated Version) Art. 17). This right is, however, "subject to the limitations and conditions laid down in [the TEU] and by the measures adopted to give it effect."

7. The Eurobarometer survey allowed respondents to give multiple responses to this question. In Poland and Germany, the percentage answering "freedom to travel, study and work anywhere in the European Union” was even higher, at 62\% and 57\% respectively (Eurobarometer 2007:Table of Results QA14).

8. TEU, Art. G, Para. 9 (Treaty Establishing the European Community (Consolidated Version) Art. 18).

9. As of 1/1/2003. Source: Eurostat.

10. Kommunale Statistikstelle der Stadt Frankfurt(Oder) (2005).

11. As of 12/31/2005. Source: Federal Statistical Office of the Republic of Germany.

12. Urząd Miejski w Słubicach (Municipal Government of Słubice), personal communication with the author, August 4, 2006.

13. The regional district containing the city of Słubice.

14. As of 1/1/2003. Source: Eurostat.

15. Unfortunately, a similar breakdown of Frankfurt(Oder)'s foreign population by citizenship was not available. 
16. Common Manual, 2002/C 313/02, (OJ C 313, 16.12.2002, p. 97). As of 13 October 2006, the Council of the European Union regulation 562/2006 (OJ L 105 , 13.4.2006, p. 1) establishing a Schengen Borders Code superseded the Common Manual. Although this fieldwork was completed before the Schengen Borders Code came into effect, the provisions that are relevant to my arguments are contained in both documents. For the sake of continuity and the aid of the reader, I reference both documents.

17. See also Schengen Borders Code, Art. 7, Para. 2. The Schengen Borders Code specifically invokes the principle of free movement of persons by calling for a minimum check on "persons enjoying the Community right of free movement." It also adds the examination of entry and exit stamps to verify that a third country national has not exceeded the maximum duration of an authorized stay to the criteria of a thorough check.

18. This is likely because the Słubice/Frankfurt(Oder) checkpoint was already scheduled to be eliminated before 2009, the date by which the Schengen Borders Code (Article 9) required these lanes to be in place.

19. Collegium Polonicum in Słubice, and European University Viadrina in Frankfurt(Oder).

20. Only 7\% of non-Schengen passport holders rated the border checkpoint as "easy" or "very easy," compared to 58\% from Schengen member states and $76 \%$ from Schengen signatories.

21. Art. 2, para. 2 of Council regulation 2133/2004 (OJ L 369, 16.12.2004, p.5), amending Art. 6 of the Convention implementing the Schengen Agreement (OJ L 239, 22.9.2000, p. 19). See also Schengen Borders Code, Art 10 Para. 1.

22. Common Manual Part 2, Point 2.1.1, See also Schengen Borders Code, Art. 10 Para. 2.

23. On June 25, 1995, these "no entry" stamps were one of the causes behind a public demonstration in Słubice that gained international attention by blocking traffic across the border bridge. The previous day, about 250 Poles from Słubice had gone to Frankfurt(Oder) in response to an advertisement offering DM 100 for a day's work distributing free newspapers. The advertisement was posted at the Stubice town hall and appeared to be legitimate, and most of the people who responded assumed that the company had secured the appropriate work permits. When the perspective employees arrived in Frankfurt(Oder), they were detained by the German border police for working illegally even though they had not yet accepted jobs. Several hours later, the Słubice residents were deported, and "noentry" stamps (officially called "administrative visas") were placed in their passports, barring their entry into Germany for five years. This decision in particular sparked the subsequent public outcry in Stubice, which eventually resulted in the cancellation of most of these stamps provided the affected individuals filed official appeals (Bajak 1995a, 1995b, 1995, PAP 1995a, 1995b).

24. Art. 10, Para. 3 of the Schengen Borders Code repeats this regulation, changing only alien to "third-country national" and indicating that the sheet should be given to that individual.

25. Although citizens of the 2004 accession countries were immediately granted the right to travel and reside anywhere in the EU after May 1, 2004, their right to 
work was subject to qualification for a transition period of up to seven years. Only the United Kingdom, Ireland and Sweden fully opened their labor markets in 2004, while Finland, Greece, Italy, Portugal, and Spain followed in 2006, and the Netherlands and Luxemburg in 2007. The labor markets of the remaining five countries, Austria, Belgium, Denmark, France, and Germany remain restricted. Cyprus and Malta were excluded from these transitional agreements, and their citizens enjoyed immediate access to all labor markets within the EU. Slovenia, Poland, and Hungary applied reciprocal labor market restrictions in 2004.

Slovenia and Poland dropped these restrictions in 2006 and 2007 respectively.

26. To be eligible for naturalization, a foreigner must have lived legally in Germany for eight years, seven years if he or she completed an integration course, or three years if the person is a spouse or a same sex partner of a German citizen (German Nationality Act as amended 15 July 1999, Sect. 9 and Sec. 10 Para. 1).

Individuals must also demonstrate knowledge of German, declare their allegiance to the German constitution, and prove that they can support themselves. A foreigner is eligible for naturalization in Poland after five years of residence on a permanent residence permit, which is usually granted only after a three-year period of temporary residence, for a total of eight years. In the case of marriage to a Polish citizen, only three years of residence are required (Statute on Polish Citizenship, Dziennik Ustaw Rzeczypospolitej Polskiej (Official Journal of Laws of the Republic of Poland) No. 28, Item 353, 5 December 2000). Poland does not have a language requirement, nor does it recognize same sex partnerships. Both Germany and Poland make provisions for granting citizenship to repatriates: Germany in Article 116 of the Basic Law (Grundgesetz), which establishes the right of return, and Poland by the Repatriation Act of 9 November 2000 (See Dziennik Ustaw Rzeczypospolitej Polskiej, 5 December 2000).

27. As a general rule, Germany requires individuals to renounce their previous citizenship before naturalization, although dual citizenship is possible in certain narrow circumstances. In Poland, dual citizenship is permitted, but an individual can be required to renounce his or her previous citizenship prior to naturalization (as was the case for Vasyl and Anastasiya).

28. All of the 2004 accession countries except Cyprus were also included in this decision.

29. This included only controls at Poland's land and sea borders. Controls at airports were not eliminated until March 2008.

30. All areas within $30 \mathrm{~km}$ of an internal Schengen border continue to be patrolled by the respective member states' border guards.

31. See Council regulation 539/2001 (OJ L 81, 21.3.2001, p. 1), and Art. 3, Para. and Annex I of the 2003 Act of Accession (OJ L 236, 23.9.2003, p. 33). This ended a bilateral policy of visa-free travel between the two countries. Ukraine, maintained its visa-free policy towards Polish citizens, and as of September 1, 2005 dropped the visa requirement for citizens of all EU member states, Switzerland, and Liechtenstein. Despite the additional bureaucratic hurdles required to obtain a visa, the requirement does not appear to have curtailed travel between Ukraine and Poland, and Poland continued to provide visas to Ukrainian nationals free of charge in order to alleviate some of the policy's effects. While 
cross-border traffic initially fell $70-90 \%$ in the days immediately following the introduction of visas (PAP 2003), the total border traffic between Poland and Ukraine increased 3.74\% between 2003 and 2004 and 46.5\% between 2004 and 2005 (Source: Straż Granica Rzeczypospolitej Polskiej). Since the Polish border guard does not report the nationality of individuals crossing the border, it is ultimately unclear what country's citizens are responsible for this dramatic increase in border traffic. In 2004, Poland issued 575,471 visas to Ukrainian citizens, and 217,935 visas at the L'viv consulate alone (the Polish consulate closest to the border), making it the busiest Polish consulate in the world (Ministerswo Spraw Zagranicznych 2004). L'viv retained the title in 2005 issuing 273,565 visas, while Ukrainian citizens were issued around 600,000 visas in total (Ministerswo Spraw Zagranicznych 2005). In accordance with the visa facilitation agreement signed between the EU and Ukraine, Poland began charging Ukrainian nationals a reduced fee of 35 Euros for Schengen visas as of December 2007. Visa fees continue to be waived for several groups, including students, journalists, pensioners, disabled persons and close relatives of people in the EU. 


\section{Works Cited}

Anderson, Benedict

1983 Imagined Communities: Reflections on the Origin and Spread of Nationalism. London: Verso.

Anderson, David

1996 Bringing Civil Soviet to an Uncivilised Place: Citizenship Regimes in Russia's Arctic Frontier. In Civil Society: Challenging Western Models. C. Hann and E. Dunn, eds. Pp. 99-120. London: Routledge.

Asher, Andrew

2005 A Paradise on the Oder? Ethnicity, Europeanization, and the EU

Referendum in a Polish-German Border City. City and Society 17(1):127151.

2008 Borderline Europeans: European Union Citizenship on the Polish-German Frontier. Doctoral Dissertation. University of Illinois at UrbanaChampaign.

Bajak, Frank

1995a Neighborly Relations? Raid By German Border Police Upsets Poles. Associated Press, June 27, 1995.

1995b Kohl Calls Reports Of Mistreatment False, Says It Won't Hurt His Visit. Associated Press, June 28, 1995.

1995c Seeking To Ease Polish Anger, Germany Offers To Cancel Entry Ban. Associated Press, June 29, 1995.

Balibar, Etienne

2004 We, the People of Europe?: Reflections on Transnational Citizenship. J. Swenson, transl. Princeton, NJ: Princeton University Press.

Brubaker, Rogers

1992 Citizenship and Nationhood in France and Germany. Cambridge, Mass.: Harvard University Press.

Cohen, Jean

1999 The Changing Paradigms of Citizenship and the Exclusiveness of the Demos. International Sociology 14(3):245-268

Council of the European Union

2000 Convention Implementing the Schengen Agreement. OJ L 239, 22.9.2000, p. 19. 
2001 Council regulation listing the third countries whose nationals must be in possession of visas when crossing the external borders and those whose nationals are exempt from that requirement. Vol. 539/2001. OJ L 81, 21.3.2001, p. 1.

2002 Common Manual. Vol. 2002/C 313/02. OJ C 313, 16.12.2002, p. 97.

2003 Council directive concerning the status of third-country nationals who are long-term residents. Vol. 2003/109/EC. Pp. 10: OJ L 16, 23.1.2004, p. 44.

2004 Council regulation on the requirement for the competent authorities of the Member States to stamp systematically the travel documents of third country nationals when they cross the external borders of the Member States and amending the provisions of the Convention implementing the Schengen agreement and the common manual to this end. Vol. 2133/2004. OJ L 369, 16.12.2004, p.5.

2006a Regulation establishing a Community Code on the rules governing the movement of persons across borders (Schengen Borders Code). Vol. 562/2006. OJ L 105 , 13.4.2006, p. 1.

2006b Press Release. 2768th Council Meeting. Justice and Home Affairs. Brussels, 4-5 December 2006. Vol. 15801/06 (Presse 341).

Deutsche Welle

2007 German Police Demonstrate against EU Border Opening. Deutsche Welle, November 23, 2007

deZayas, Alfred M.

1979 Nemesis at Potsdam: The Anglo-Americans and the Expulsion of the Germans, Background, Execution, and Consequences. London: Routledge.

d'Oliveira, Hans Ulrich Jessurun

1995 Union Citizenship: Pie in the Sky? In A citizens' Europe: In search of a New Order. A. Rosas and E. Antola, eds. Pp. 58-84. London ; Thousand Oaks, Calif.: SAGE Publications.

Donnan, Hastings, and Thomas M. Wilson

1999 Borders: Frontiers of Identity, Nation and State. Oxford: Berg.

Eurobarometer

2007 Standard Eurobarometer 65/2006: Eurostat.

Foucault, Michel

1991 Governmentality. In The Foucault Effect: Studies in Governmentality. G. Burchell, C. Gordon, and P. Miller, eds. Pp. 87-104. Chicago: University of Chicago Press. 
2007 Security, Territory, Population: Lectures at the Collège de France, 19771978. New York: Palgrave Macmillan.

Gordon, Colin

1991 Governmental Rationality. In The Foucault Effect: Studies in

Governmentality. G. Burchell, C. Gordon, and P. Miller, eds. Pp. 1-52.

Chicago: University of Chicago Press.

Humphrey, Caroline

1999 Citizenship Regimes in Provincial Russia. In Uncertain Transition:

Ethnographies of Change in the Postsocialist World. M. Burawoy and K. Verdery, eds. Pp. 19-52. Lanham, MD: Rowman \& Littlefield

Inda, Jonathan Xavier

2005 Analytics of the Modern: An Introduction. In Anthropologies of Modernity: Foucault, Governmentality, and Life politics. J. X. Inda, ed. Pp. 1-22. Oxford: Blackwell.

International Civil Aviation Organization (IACO)

2003 Document 9303. Machine Readable Travel Documents. Part 1: Machine Readable Passports.

Kastoryano, Riva

2002 Negotiating Identities: States and Immigrants in France and Germany. B. Harshav, transl. Princeton: Princeton University Press.

2003 Between Europe and Nation-States: The Turkish Transnational Community. In Identity and Integration: Migrants in Western Europe. R. Sackmann, B. Peters, and T. Faist, eds. Pp. 189-204. Aldershot, Eng.: Ashgate.

Kipnis, Andrew

2004 Anthropology and the Theorisation of Citizenship. The Asia Pacific Journal of Anthropology 5(3):256-278.

Kommunale Statistikstelle der Stadt Frankfurt(Oder)

2005 Statistischer Bericht: Sozio-demografische Daten der Stadtgebiete im Vergleich. Vol. 01/2005.

Kostakopoulou, Theodora

2001 Citizenship, Identity, and Immigration in the European Union: Between Past and Future. Manchester: Manchester University Press.

Märkische Oderzeitung (MOZ) 
2007a Sicherheit in Grenzregion: Schäuble tritt Ängsten entgegen. Märkische Oderzeitung, November 22, 2007.

2007b Feuerwerk und Musik an der Grenze zu Polen. Märkische Oderzeitung, December 21, 2007.

2007c Schengen-Zone: Platzeck erwartet neuen Schub für das Land. Märkische Oderzeitung, December 21, 2007.

Miller, Peter, and Nikolas Rose

1990 Governing Economic Life. Economy and Society 19(1):1-31.

Ministerstwo Spraw Zagranicznych

2004 Departament Konsularny i Polonii Raport o Pracy Polskiej Służby Konsularnej w 2004 Roku

2005 Departament Konsularny i Polonii Raport o Pracy Polskiej Służby Konsularnej w 2005 Roku

Ong, Aihwa

1996 Cultural Citizenship as Subject-Making: Immigrants Negotiate Racial and Cultural Boundaries in the United States. Current Anthropology 37(5):737-762.

1999 Flexible Citizenship : the Cultural Logics of Transnationality. Durham: Duke University Press.

Peebles, Gustav

1997 "A Very Eden of the Innate Rights of Man"? A Marxist Look at the European Union Treaties and Case Law. Law and Social Inquiry 22(581):581-616.

Polish Press Agency (PAP)

1995a Frankfurt Authorities to Invalidate Ban on Poles to Enter Germany. PAP News Wire, June 29, 1995.

1995b Frankfurt Incident Explanation: Prosecutors in Frankfurt-on-Oder Elaborate on Incident there. PAP News Wire, June 30, 1995.

2003 Border traffic falls by up to 90 pct after visa introduction. PAP News Wire, Oct. 2, 2003.

Rose, Nikolas, and Peter Miller

1992 Political Power beyond the State: Problematics of Government. The British Journal of Sociology 43(2):173-205.

Schnapper, Dominique 
1998 Community of Citizens: On the Modern Idea of Nationality. New Brunswick, N.J.: Transaction Publishers.

Shore, Chris

2000 Building Europe: The Cultural Politics of European Integration. London: Routledge.

Soysal, Yasemin

1994 Limits of Citizenship: Migrants and Postnational Membership in Europe. Chicago: University of Chicago.

Tilly, Charles

1996 Citizenship, Identity and Social History. Cambridge: Cambridge University Press.

Torpey, John C.

2000 The invention of the Passport: Surveillance, Citizenship, and the State. Cambridge: Cambridge University Press.

Wiener, Antje

1998 'European' Citizenship Practice: Building Institutions of a Non-State. Boulder, Colo.: Westview Press. 